\title{
Śladami pierwszych misjonarzy protestanckich w Himalajach ${ }^{1}$
}

\section{Prolog}

W yjeżdżając po raz pierwszy do Indii północnych w 1996 r. w celu przeprowadzenia badań terenowych, nie byłem świadom długotrwałej obecności Europejczyków na tym obszarze. Więcej, nie podejrzewałem, że ktokolwiek osiedliłby się tam z własnej woli. Z dostępnych mi wówczas źródeł (absolutne początki ery internetowej) wynikało, iż najdalej na północy Indii działali członkowie rodziny Roerichów, ale mieszkali oni w Nagarze, w dolinie Kulu, a zatem kilka dni drogi pieszo od okręgu Lahul. Inni Europejczycy - podróżnicy, odkrywcy, oficjele brytyjscy, a nawet szpiedzy, bywali tam sporadycznie, a ich wizyty były krótkotrwałe.

Moje wcześniejsze pobyty w Indiach, poczynając od 1989 r., nie dawały żadnych podstaw do bliższego poznania specyfiki życia wysokogórskich społeczności

\footnotetext{
${ }^{1}$ Wskazuję w tym miejscu na pionierskość działań misyjnych przedstawicieli Jednoty Morawskiej z Herrnhutu, w Saksonii. To zgromadzenie, jako pierwsze wśród denominacji protestanckich, podjęło planowe działania ewangelizacyjne (od 1732 r.), choć późno objęły one ludność zamieszkującą obszar wysokogórski Himalajów (od 1853 r.). W znacznie szerszym rozumieniu pas himalajski obejmuje także przedgórza, a w tamtym rejonie przed morawianami działali misjonarze z Church Mission Society (brytyjska organizacja powołana w 1799 r., werbująca współpracowników spośród członków różnych innych ugrupowań protestanckich), z siedzibą w Kotgarh k/Śimli, a także Baptist Mission Society, którego członkowie działali od początków XIX w. w Dardżylingu i w Butanie (doskonałym źródłem streszczającym wątek protestanckiego zaangażowania na północy Indii jest: Bray 2005).
} 
tego regionu, czy też odczuwania familiarności z innymi grupami etnicznymi tego subkontynentu. Kilkukrotne wyjazdy do Nepalu, nawet uczestnictwo w trekkingach, również nie skutkowały poczuciem znajomości terenu i jego różnorodności kulturowej. Byłem zachwycony himalajską przyrodą i zapewne ta fascynacja, patrząc z perspektywy minionych lat, gnała mnie tam kolejny raz.

Planowana na rok wyprawa, rozpoczęta we wrześniu 1996 r., skurczyła się do ośmiu miesięcy. Odwiedzane miejsca, głównie na północy Indii, były dość starannie dobrane, ze względu na realizowane zadania badawcze mojego kolegi Przemysława Hincy ${ }^{2}$ (gospodarka pasterska w rozumieniu koegzystencji grup himalajskich i zwierząt) i moje zainteresowania (tradycyjne pszczelarstwo na obszarze stanu Himaćal Pradeś). Była to wówczas dość odważna decyzja, aby w taki sposób pozyskać materiały do prac magisterskich, bez odpowiedniego zaplecza finansowego i sieci znajomych na miejscu. Jednakże nie byliśmy aż tak niefrasobliwi, jak mogłoby się z tego opisu wydawać. Zrobiliśmy wiele, by nasz wyjazd doszedł do skutku i aby móc się na miejscu utrzymać. W ambasadzie RP w New Delhi określano nas żartobliwie mianem „pasterze i pszczelarze”.

Ostatecznie dojechaliśmy do Kinnauru, który zauroczył nas na długo, zarówno badawczo, jak i prywatnie. I to się nie zmieniło do dzisiaj. Przejechaliśmy tysiące kilometrów, a przeszliśmy piechotą setki, w najwyższych częściach Himaćal Pradeś, jak i sąsiedniego stanu Uttar Pradeś ${ }^{3}$. Nigdzie nie było tak pięknie. Kiedyś odczuwałem trochę wstydu z powodu tak arbitralnego i prozaicznego argumentu na rzecz wyboru "mojego” miejsca badań. Po latach nie mam sobie nic do zarzucenia. Okręg Lahul sąsiaduje z moim ulubionym obszarem badań, a więc znajduje się na drugim miejscu mojej listy preferowanych miejsc w tej części Azji.

\section{Morawianie. Pierwsze ślady}

Chociaż moją ówczesną uwagę koncentrowałem na pszczelarstwie, jego miejscu w lokalnej ekonomii, ewentualnych związkach apikultury z szerokim spektrum wierzeń i rytuałów, to zwracałem również uwagę na elementy codziennego życia tamtejszych mieszkańców, jakby żywcem wyjęte z alpejskich czy karpackich wiosek. Dzisiaj uważam, że nawet łatwo było je za pierwszym razem przeoczyć. Tak bardzo przypominały one aktywności rękodzielnicze obecne na naszym Podhalu, że można je było uznać za spójny element himalajskich kultur. I tak, skoro nie zauważyłem ich od razu (na poziomie obserwacji ogólnej), to przykuły one moją uwagę podczas kontaktów bezpośrednich (w czasie wywiadów i obserwacji zogniskowanych). Przedstawiciele obu płci byli zajęci przędzeniem wełny, a mniej liczna grupa, wyłącznie kobiet, specyficznym splataniem jej, co potocznie

\footnotetext{
2 Przemysław Hinca, wówczas magistrant, później adiunkt zatrudniony do 2011 r. w Instytucie Etnologii i Antropologii Kulturowej UAM, obecnie poza sferą aktywności akademickiej. ${ }^{3}$ W 2000 r. stworzono z północnej części stanu Uttar Pradeś nowy stan Uttarańcal, a następnie przemianowano go w 2006 r. na Uttarakhand. Ta nazwa i granice administracyjne stanu obowiązują do dzisiaj.
} 
jest nazywane „robieniem na drutach”. Jako że pochodzę z zachodniej części Polski, popularność tego zajęcia wiązałem dość bezrefleksyjnie z niemieckimi wpływami kulturowymi. Jednakże każde pytanie o ten rodzaj rzemiosła przynosiło niezmienną odpowiedź, że jest to tradycyjne zajęcie, charakterystyczne dla Lahulu, Kinnauru i okolic. Żaden z rozmówców nie potrafił wskazać związku „robienia na drutach" z wpływami zewnętrznymi. Powoływali się na przekaz międzypokoleniowy. Jakichkolwiek poszerzających tę wiedzę odpowiedzi nie można było od nich uzyskać. Motywy zdobnicze obecne w tych wyrobach, jak i częściowe stosowanie włókien sztucznych, tudzież barwników różnorodnego pochodzenia, też nie przybliżały mnie do rozwiązania tej zagadki.

Drugim, ewidentnie obcym, elementem były tam krosna - szerokie i poziome, a więc zdecydowanie nieprzystające do "tamtego świata". Był to oczywisty import kulturowy, ale ponownie niejasnego pochodzenia. Dzisiaj taka sytuacja wydawać się może absurdalna, a piszący te słowa - zupełnym ignorantem. Należy tylko wziąć pod uwagę ówczesną skromną zasobność polskich specjalistycznych bibliotek oraz i ten fakt, że zamówienie książki za pośrednictwem wypożyczalni międzybibliotecznej UAM trwało zwykle od dwóch do trzech miesięcy ${ }^{4}$. Poza tym wówczas interesowały mnie głównie publikacje związane bezpośrednio z tematem pracy. Trzeba więc było dokonywać bolesnych wyborów, a potem często okazywało się, że zawartość długo wyczekiwanej książki nie odpowiadała ściśle tytułowi. Każda taka sytuacja oznaczała dotkliwą stratę kilku miesięcy. Wysyłałem też wiele listów do zagranicznych autorów, od których zazwyczaj otrzymywałem spore pakiety nadbitek. Sądzę, że szczególnie przedstawiciele młodego pokolenia antropologów nie wyobrażają sobie, jak można było wówczas pracować naukowo, bądź co bądź efektywnie i twórczo, bez gotowych bibliografii, bez sprawdzenia potrzebnych haseł w wyszukiwarkach internetowych, bez możliwości ściągnięcia plików i tym podobnych ułatwień, które dzisiaj są powszechne.

Nie udało mi się podczas pierwszego pobytu w Himalajach znaleźć odpowiedzi na pytania, w jaki sposób i dzięki jakiemu pośrednictwu doszło w tym rejonie do adopcji importów kulturowych. Dopiero po powrocie do kraju miałem okazję rozmawiać z Piotrem Klafkowskim ${ }^{5}$, przy okazji wykładów prowadzonych przez niego na uniwersytecie w Poznaniu. Podczas spotkania podzieliłem się moimi wątpliwościami (i ignorancją), a on potrafił naprowadzić mnie na właściwy kierunek poszukiwań. Wreszcie ktoś był w stanie nakreślić jakiś spójny obraz historii europejskich kontaktów z tamtym rejonem świata.

Potrafił on także wskazać wiele źródeł, do których dotychczas nie miałem dostępu. To był początek naszych dyskusji (choć wówczas byłem tylko

\footnotetext{
${ }^{4}$ Wypożyczalnia międzybiblioteczna działała na takiej zasadzie, że - aby zamówić następną książkę - trzeba było zwrócić bieżącą. Przy bardzo sprawnej organizacji można było pozyskać trzy, cztery pozycje zagraniczne rocznie.

5 Piotr Klafkowski, tybetolog, autor między innymi słynnego tłumaczenia poezji autorstwa VI Dalaj Lamy Tybetu [Klafkowski, P. (1979). The Secret Deliverance of the Sixth Dalai-Lama. Wiener Studienzur Tibetologie und Buddhismuskunde, 3.] i innych przekładów tekstów tybetańskich zapisanych językiem klasycznym.
} 
słuchaczem). Trzeba mieć szczęście, aby spotkać na swojej drodze ludzi kompetentnych, którzy potrafią słuchać i mają umiejętność wspomagania swą wiedzą samodzielnych poszukiwań. Wówczas dowiedziałem się pierwszy raz o Braciach Morawskich w Indiach i o ich niemieckich korzeniach.

\section{Morawianie. Odsłona druga}

Przez ponad rok zajmowały mnie inne sprawy, ale o morawianach nie zapomniałem. Zgromadziłem trochę źródeł dotyczących Braci Czeskich, odwiedziłem także Kościan, Leszno, Szamotuły i kilka innych wielkopolskich ośrodków znanych z przeszłości ariańskiej. Przyznaję, że dopiero wówczas poczułem chęć poznania ich myśli i założeń na poziomie nieco głębszym niż w czasie edukacji szkolnej. Była to podróż zaskakująca i z pewnością owocna. Nigdy specjalnie nie interesowało mnie dawne szkolnictwo, projekty pedagogiczne, związki rzemiosła ze światopoglądem, a także idee „uświęcania” swego życia poprzez codzienne zajęcia. Poznanie protestanckiego etosu pracy, (moje ówczesne poznanie trudno byłoby nazwać zgłębieniem), w tym szczególnym przypadku ideologii skrajnego odłamu ewangelików i zarazem pietystów, skłoniło mnie do wyboru tematyki pracy doktorskiej związanej właśnie z Herrnhuterami ${ }^{6}$. Co istotne i dla mnie ważne, można było tych misjonarzy powiązać $\mathrm{z}$ wybranym przez mnie terenem badań w Himalajach. Szczyt szczęścia7.

Proza życia, czyli brak środków na prowadzenie zagranicznych badań, wstrzymywała mnie z realizacją tego projektu. Nie mając możliwości sfinansowania wyjazdu, mogłem jedynie opracowywać nieliczne źródła wtórne. Sytuacja zmieniła się, gdy otrzymałem niewielki acz wspomagający grant z Instytutu Archeologii i Etnologii PAN, w którym wówczas pracowałem. W dodatku stał się on dopełnieniem grantu przyznanego mi w międzyczasie przez Research Support Scheme z Pragi. Cieszyłem się ogromnie z jego uzyskania, ale zupełnie nie zdawałem sobie sprawy, jakie miałem szczęście. Zapewne czeskich recenzentów ujął nieznany im wymiar aktywności grupy religijnej związanej z myślą Jana Husa. Ważne było to, że miałem wreszcie środki na dwa lata pracy, utrzymanie powiększającej się rodziny i na krótki wyjazd badawczy. Niewiarygodne, jak te fundusze były wtedy potrzebne ${ }^{8}$.

\footnotetext{
${ }^{6}$ Saksońskich morawian nazywał herrnhuterami tłumacz dziennika podróży Jana Potockiego (Podróż przez Stepy Astrachania i na Kaukaz 1797-1798), przy okazji opisu ich działań w Sarepcie (dzisiaj dzielnica Wołgogradu).

7 Ograniczam tutaj przestawienie dylematów, opinii przełożonych i szeregu innych przeciwności, których intensywność, uciążliwość i znaczenie mocno już zatarł miniony czas.

8 Zaznaczam fakt uzyskania grantu, choć zdaję sobie sprawę, że nie ujawniam szczegółów. Nie chcę czynić w tekście nazbyt daleko idących osobistych uwag i odsłaniać kulis wielu decyzji życiowych. Uważam, że ich opisanie nie jest niezbędne do zrozumienia powagi sytuacji, choć zapewne skrótowość przedstawienia nie pozwala na poznanie ówczesnych priorytetów, moich osobistych, jak i pośrednio badawczych.
} 
Najpierw rozpocząłem pracę studyjną w archiwum Braci Morawskich w Herrnhucie. Miałem wówczas wrażenie, iż wszystko przychodzi mi łatwo. Dość oczywistym faktem było znalezienie tam ogromu materiałów źródłowych, w tym kilku tysięcy stron rękopiśmiennych dokumentów, sprawozdań, listów, notatek, prób tłumaczeń, rysunków, kopii tekstów przygotowywanych do druku, setek zdjęć ${ }^{9}$ i tym podobnych źródeł. Większość tych dokumentów była w języku niemieckim, którego znajomością niestety nie dysponowałem. W dodatku spora część tych źródeł nie była wtedy nawet skatalogowana. Wydawało się, że jest to praca na całe życie. Nie mogłem przecież z tego powodu przenieść się do Saksonii. Trzeba było tak zorganizować zajęcia, bym mógł pracować w domu. W tym zakresie okazano mi daleko idącą pomoc. Dzięki życzliwości ze strony pracowników Muzeum Etnograficznego w Dreźnie, ich oddziału w Herrnhucie, kierownictwa archiwum, a nawet kilku badaczy historii misji morawskich obecnych w czasie moich wizyt w archiwum, udało mi się uzyskać wiele kopii materiałów, za które oficjalnie musiałbym sporo zapłacić ${ }^{10}$, a do tego miałem gdzie przenocować, z kim porozmawiać i kogo się poradzić.

Żeby zrozumieć działalność Braci Morawskich w Himalajach (Morawian Brüdergemeinde, Jednota Braterska, Moravian Brethren, Unitas Fratrum) zacząłem się wczytywać w dokumenty i opracowania dotyczące ich doktryny i aktywności. Stopniowe poznawanie intencji członków wspólnoty przynosiło cząstkową wiedzę dotyczącą sposobu ich życia, organizacji zgromadzenia, a w końcu procedur towarzyszących prowadzeniu działań misyjnych. Dopiero wtedy pojąłem, o czym mówili wykładowcy podczas wielu zajęć na poznańskiej etnologii, kiedy to wspominali, jak ważne jest umiejętne łączenie badań etnohistorycznych z terenowymi. W tym przypadku taka fuzja była najrozsądniejszym podejściem metodologicznym. Ponadto znowu byłem szczęściarzem. Będąc zatrudnionym na etacie asystenta, nie musiałem się spieszyć, jak miałoby to miejsce na studiach doktoranckich. Nawet więcej, na trzyletnich studiach nie mógłbym podjąć się opracowania takiego tematu. Zbyt wiele materiałów archiwalnych wymagało najpierw odcyfrowania (rękopisy), uporządkowania, przetłumaczenia i zweryfikowania. Po wykonaniu tej części prac, z pewnością trochę na wyrost, poczułem się zaznajomiony z tematyką, szczególnie wówczas, gdy zacząłem znajdować luki i błędy w nielicznych opracowaniach dotyczących historii morawskiej misji himalajskiej ${ }^{11}$. Jednakże trzeba zdawać sobie sprawę z tego, że podejmując się

\footnotetext{
${ }^{9}$ We wspomnianym archiwum znajduje się między innymi kilkaset zdjęć z drugiej połowy XIX w., utrwalonych na płytkach szklanych. Z tego, co mi wiadomo, dawne plany kierownictwa archiwum, by je opisać i opublikować, nie zostały sfinalizowane.

${ }^{10}$ Każdy, kto pracował w archiwum, wie, iż uzyskiwanie kopii materiałów może być horrendalnie drogie. Na początku mojej pracy kopia kserograficzna kartki formatu A4 wyceniana była w Archiwum Braci Morawskich w Herrnhucie na 0,5 DM. Biorąc pod uwagę wielką liczbę rozmaitych tekstów dla mnie interesujących, sfinansowanie takiej usługi przekraczałoby kwotę całego mojego grantu.

${ }^{11}$ Oficjalnie działalność morawian w Himalajach nosiła miano „misji tybetańskiej”, ponieważ takie były pierwotne intencje wspólnoty. Używam sformułowania „misja himalajska”, aby nie wprowadzać dodatkowego elementu wymagającego każdorazowo tłumaczenia.
} 
badań etnohistorycznych, w przypadku, gdy ma się do dyspozycji znaczną obfitość i różnorodność źródeł, trudno wskazać odpowiedni moment, w którym należy zakończyć pracę z archiwaliami. Po niemal 20 latach wciąż znajduję jakieś niewykorzystane listy, notatki, druki, a co najważniejsze - ciągle ukazują mi się nowe konteksty, które pozostawały dotąd przede mną ukryte.

W tym szkicu odnoszę się tylko do początków działań misjonarzy morawskich, gdyż członkowie tej wspólnoty pozostawali czynni w Himalajach przez niemal sto lat. Wśród nich spotkać było można różne postacie, które przebywały na misjach w kolejnych fazach działalności ewangelizacyjnej, charakteryzowali się oni zróżnicowanym wykształceniem, zdolnościami, stanem zdrowia, a nawet przyzwyczajeniami i fobiami. Nie sposób byłoby zrozumieć działań tych Europejczyków i rezultatów ich poczynań bez możliwości dotarcia do źródeł, dzięki którym bohaterowie tych wydarzeń ukazują się nam w „ludzkim trójwymiarze”. Gdyby brakowało archiwaliów lub nie brało się ich pod uwagę, wówczas w analizie rozpatrywane byłyby tylko te elementy, które zostały utrwalone w terenie. $\mathrm{W}$ takiej sytuacji fundamenty analizy etnologicznej/antropologicznej zostałyby wyraźnie zubożone.

\section{Bracia Morawscy a działalność misyjna}

Wspólnota Unitas Fratrum powstała w 1727 r., w założonej na „surowym korzeniu" osadzie nazwanej Herrnhut, w Saksonii. Miejsca w swoich włościach użyczył osiedleńcom młody hrabia Nicolas von Zinzendorf (w początkowym etapie negocjacji miał 22 lata). Powodem migracji małych grup wywodzących się z Czech była chęć znalezienia spokojnego miejsca, w którym zapewniono by im pełną swobodę praktyk religijnych. Rozmowy temu towarzyszące i budowa wsi trwały niemal pięć lat (od 1722 r.). Trzon osady tworzyło początkowo kilkanaście rodzin. W tym okresie Zinzendorf nie był ani członkiem wspólnoty, ani też nie znał szczegółów doktryny, której wyznawcy zamieszkali na jego ziemiach. Tymczasem z biegiem lat zaczęli oni stanowić dla niego niemały kłopot, ponieważ nie godzili się na podległość hierarchii Kościoła ewangelicko-augsburskiego, co nie spotkało się z aprobatą na dworze króla Saksonii - Fredericka Christiana ${ }^{12}$.

We wspomnianym 1727 r. doszło także do brzemiennego w skutki wydarzenia. W ówczesnym Herrnhucie zamieszkiwali już przedstawiciele różnych skrajnych odłamów ewangelickich, którzy ściągali tam na wieść o dogodnym miejscu oferującym swobody wyznaniowe. Jednakże różnice doktrynalne spowodowały spory, a te z kolei wpływały na destabilizację tworzących się grup. Tymczasem Zinzendorfowi coraz trudniej było wytłumaczyć się na saksońskim dworze z udzielenia schronienia uchodźcom z kilku państw niemieckich oraz

12 Obaj arystokraci byli przyjaciółmi od dziecięcych lat. Ta więź spowodowała, iż N.L. von Zinzendof był traktowany przez króla w szczególny sposób. Przez kilkanaście lat niestosowanie się do królewskich zaleceń przynosiło w konsekwencji wyłącznie upomnienia. Ostateczny wyrok banicji także kilkukrotnie był przekładany. 
z Czech. Wedle tradycji ugrupowania, po kilkudniowych modlitwach nastąpiło Zesłanie Ducha Świętego. W religijnym uniesieniu podjęto entuzjastyczną decyzję o utworzeniu nowej wspólnoty. Poza ingerencją sił nadprzyrodzonych potrzebna była praca u podstaw, spisanie nowej, jednoczącej doktryny i ustalenie szczegółowych zasad funkcjonowania grupy. Zinzendorf, poniesiony odczuciem wagi chwili, zdecydował się na objęcie przewodnictwa, także duchowego, nad nową wspólnotą, jak i na rezygnacje z dotychczasowych stanowisk na dworze królewskim. Ta proklamacja spowodowała niemałe zamieszanie w najwyższych kręgach władców niemieckich. Ławo sobie wyobrazić, jak odczytano decyzję arystokraty, wprawdzie z niewielkiego księstwa, o faktycznym wypowiedzeniu posłuszeństwa władcy i dotychczasowej strukturze kościelnej. Sprawa ta ciągnęła się przez dziesięciolecia i zakończyła się skazaniem Zinzendorfa na banicję, ale także przyczyniła się do utworzenia własnej linii biskupów herrnhuckich.

Zainteresowało mnie szczególnie to, z jakich powodów młody arystokrata sprzeciwił się królowi i postawił na szali swój majątek, dostatnie życie na dworze, i wielorakie przywileje, by przewodzić grupie, której przyszłość była niepewna. Dzisiaj pewnie taką sytuację określilibyśmy jako eksperyment ${ }^{13}$. Nie opisywałem dotąd tego wątku, traktując go jako zbyt biograficzny, i do tego nazbyt wykraczający poza ramy etnologii. $W$ tym przypadku ponownie badania etnohistoryczne przynoszą zaskakujące wnioski. Otóż Zinzendorf przeformułował swą osobistą wiarę pod wpływem przedstawicieli różnych grup obecnych w Herrnhucie. Zaczął pisać hymny, dokumenty doktrynalne, rozprawy, z których jest do dzisiaj znany ${ }^{14}$.

Związek bezpośredni z kulturami himalajskimi przyniosła decyzja władz wspólnoty herrnhuckiej, zaaprobowana przez wszystkich członków osady, a potem kilku osad, o konieczności podjęcia działalności misyjnej. Dla morawian, ewangelików i pietystów, wynikała ona wprost z analizy tekstu Nowego Testamentu. Tyle że wśród grup protestanckich nikt tego jeszcze wtedy nie czynił. Morawianie, herrnhuterzy, jak ich w Polsce nazywano, zainicjowali misje niemal

\footnotetext{
${ }^{13}$ Nie kontynuuję tego wątku. Zainteresowanych odsyłam do mojej książki Bracia Morawscy a kultury himalajskie, PTL-IAE PAN, Wrocław-Warszawa, 2011 oraz jej wersji angielskojęzycznej dostępnej on-line https://www.academia.edu/28260462/Beszterda_Moravian_Brethren_ and_Himalayan_Cultures.pdf lub licznych opracowań dotyczących historii Kościoła morawskiego z Herrnhutu, a także publikacji zgłębiających doktrynę Jednoty (zob. August Gottlieb Spangenberg, An Account of the Manner in Which the Protestant Church of the UnitasFratrum, or United Brethren, Preach the Gospel, and Carry on Their Missions Among the Heathen, H. Trapp, London 1788; James Reetzke, Count Zinzendorf. A Brief History of the Lord's Recovery, vol. 1-2, Chicago Bibles and Books, Chicago 2000-2001; Peter Zimmerling, Nikolaus Ludwig Graf von Zinzendorf und die Herrnhuter Brudergemeine, Hanssler Verlag, Holzgerlingen 1999).

${ }^{14}$ N.L. von Zinzendorf jest autorem ponad tysiąca hymnów, z których wiele jest do dzisiaj wykonywanych $\mathrm{w}$ kościołach protestanckich. Jednakże jego niektóre rozważania uznane zostały za heretyckie i bezbożne. Dotyczy to szczególnie cielesności i macierzyństwa Matki Boskiej, a także ludzkiej natury Jezusa Chrystusa.
} 
sto lat przed innymi inspiratorami podobnych inicjatyw (metodystami i baptystami), znacznie bardziej dzisiaj znanymi ${ }^{15}$.

W ich przypadku, ponownie doszła do głosu specyfika owej wspólnoty i działań jej członków. Podejmowali oni misje ewangelizacyjne w lokalizacjach najbardziej oddalonych od Europy i słabo znanych. Dzięki osobistym kontaktom ich przywódcy, Zinzendorfa, z dworem duńskim, uzyskali zgodę, i pomoc, na rozpoczęcie działań ewangelizacyjnych na obszarach kolonii początkowo tylko tego państwa. Już pięć lat po utworzeniu ugrupowania (w roku 1732) wysłali swych misjonarzy, zwykłych rzemieślników, na Wyspę św. Tomasza (wówczas w archipelagu duńskich Wysp Dziewiczych). Kolejne stacje misyjne powstały wkrótce na karaibskich wyspach św. Jerzego, Antigui, Barbadosie, Trinidadzie i Tobago, a także na Grenlandii, w Południowej Afryce i wielu innych miejscach na niemal wszystkich kontynentach. Ostatecznie, jak podkreślają historycy kościoła protestanckiego, w trakcie pierwszych trzech dekad swej działalności zagranicznej morawianie z Herrhutu „wysłali więcej misjonarzy niż cały kościół protestancki w trakcie dwustu lat” - dokładnie 312 osób w latach 1732-1760"16. W późniejszym okresiedziałania zgromadzenia były wspierane jednocześnie przez stu kilkudziesięciu misjonarzy, i ta tendencja utrzymywała się aż do czasów pierwszej wojny światowej ${ }^{17}$.

Niezwykle interesujący okazał się styl prowadzenia wczesnych misji przez morawian. Nie były one metodycznie przygotowane. Uznawano bowiem, że ich powodzenie w dużej mierze zależy od boskiej pomocy. Resztą mieli się zająć członkowie wspólnoty wybrani w trakcie uroczystego losowania, poprzedzonego długotrwałą modlitwą. Trzon pierwszych grup wysyłanych na misje stanowiło dwóch mężczyzn. Ich zadaniem było rozpoznanie terenu i możliwości prowadzenia ewangelizacji oraz założenie stacji, od strony logistyczno-bytowej. Nie znali oni języków obcych, nie posiadali zaplecza finansowego, map i sprzętu gospodarczego. Do czasu założenia misji himalajskiej wiele się jednak zmieniło w zakresie przygotowania młodych misjonarzy do życia z dala od Europy. Przechodzili oni kursy pomocy medycznej, uczyli się podstaw języków obcych, zgodnie z regionem wyjazdu. Wciąż jednak zakres ich kształcenia był dalece nieadekwatny do potrzeb rozwiązywania setek problemów logistycznych, gospodarczych i kulturowych na docelowym miejscu. Misjonarze byli całkowicie podlegli Zarządowi Misji mieszczącemu się w Herrnhucie. Każda poważna

\footnotetext{
${ }^{15}$ Misje wspólnoty Unitas Fratrum z Herrnhutu były stawiane za wzór do naśladowania $\mathrm{w}$ świecie protestanckim. Wielokrotnie podkreślano ich zaangażowanie, jak i konsekwencję działań, przy minimalnym wsparciu zewnętrznym. Doświadczeni morawscy misjonarze pełnili funkcje doradcze i byli wykładowcami w licznych kolegiach ewangelickich przygotowujących do pracy w placówkach pozaeuropejskich.

16 Austin-Sparks, T. (1970). The Lord is Risen Indeed. Witness and a Testimony, 48(3), 51. Za: Reetzke (2000: 27).

${ }_{17}$ Anderson (1874: 345). Wraz z rozpoczęciem działań wojennych, obywatele niemieccy przebywający na obszarze kolonii brytyjskich, zostali internowani. Aby utrzymać ciągłość misji, musieli zostać wymienieni na Brytyjczyków, co nie zawsze było łatwe. Po zakończeniu I wojny światowej misjonarzom niemieckiego pochodzenia nadal nie wydawano zezwoleń na pobyt w koloniach brytyjskich, bowiem traktowano ich jak szpiegów.
} 
decyzja była zatem podejmowana w Europie, i to w czasach, gdy wymiana listów pomiędzy tak odległymi zakątkami świata a Europą trwała nawet dwa lata.

Herrnhuterzy zdawali sobie sprawę z konieczności uzyskania podstaw ekonomicznych swej działalności. Za sprawą uchodźców z Czech, prawdziwych husytów, wspólnota morawska w Europie działała niemal od początku swego istnienia jak gospodarstwo, które miało zapewnić samowystarczalność swym członkom, a nadwyżki były przeznaczane na wsparcie misji1". Poza uprawą roli zajmowano się produkcją narzędzi, wozów konnych, tkactwem i szyciem odzieży ${ }^{19}$. Wyroby były sprzedawane na okolicznych targach. Poza wstępnym okresem, raczej niefrasobliwym pod względem zarządzania finansami (co doprowadziło niemal do bankructwa Zinzendorfa z powodu dodatkowych wydatków związanych właśnie z pomocą na rzecz misji), ciężka praca członków ugrupowania pozwalała na subwencjonowanie przedsięwzięć ewangelizacyjnych.

\section{Misja himalajska}

W 1853 r., przez Kalkutę, dotarli do północnych Indii dwaj młodzi mężczyźni, August Wilhelm Heyde (31 lat, pomocnik hydraulika) i Eduard Pagell (33 lata, kamieniarz). Ich zamiarem było chrystianizowanie ludów Tybetu, mimo iż, jak sami później pisali, nie mieli pojęcia ani o tym, gdzie Tybet leży, ani z czym przyjdzie im się zmierzyć. Wedle bardzo zgrubnego planu obmyślanego w Herrnhucie, mieli szybko poznać język tybetański, znaleźć dogodne przejście między Indiami Brytyjskimi a Dachem Świata, a następnie założyć stałą misję i zająć się tłumaczeniem Nowego Testamentu. W ciągu dwóch lat pobytu nie zdołali wypełnić żadnego z wymienionych punktów tego planu. Podczas licznych podróży znaleźli co prawda kilka dróg prowadzących do Tybetu z Indii północnych, ale eksploracja wnętrza państwa okazała się niemożliwa. Nauka języka szła im opornie, ze względu na spore rozbieżności między literackim a mówionym tybetańskim. W dodatku w Lahulu, na którego obszarze zdecydowali się na wybudowanie swej siedziby (wciąż traktując to miejsce jako punkt wypadowy do wyjazdów na obszar Tybetu), używano jeszcze kilku dodatkowych języków (lahuli, manchad, tinan, bunan oprócz pahari i forsowanego przez Brytyjczyków urdu), co nie ułatwiało codziennej komunikacji z mieszkańcami, także i podjęcia decyzji, na który z tych języków należy zacząć przekłady Ewangelii, by można je było upowszechniać.

Po okresie niepowodzeń, poprosili swą rodzimą kongregację o pomoc, przede wszystkim lingwistyczną. Skierowano więc do Indii najlepszego ówczesnego

${ }^{18}$ Grupy czeskie były wprawione w długotrwałym życiu „podziemnym”. Większość mężczyzn potrafiła się utrzymać z działalności rzemieślniczej. Ta umiejętność była bardzo ważnym elementem decydującym o przyjęciu adeptów do wspólnoty w Herrnhucie. Jeden z punktów przesłuchania kandydata brzmiał następująco: „czy starający się o zgodę na zamieszkanie potrafi utrzymać siebie i swą rodzinę z własnej pracy?".

${ }_{19}$ Chyba najbardziej znanym $\mathrm{z}$ wyrobów herrnhuckich są podświetlane gwiazdy adwentowe z kolorowej bibuły, choć mało kto zna ich prawdziwy rodowód. 
językoznawcę, nauczyciela w gimnazjum prowadzonym przez Braci Morawskich w Niesky, Heinricha Augusta Jaeschke. Został on mianowany kierownikiem misji tybetańskiej, jak ją nazywano w dokumentach, i wyjechał z Europy w $1856 \mathrm{r}$. Jaeschke był nietuzinkową postacią. Znał kilkanaście języków, klasycznych i nowożytnych. Interesował się malarstwem, grał na skrzypcach, rysował, dokonywał obserwacji astronomicznych. Posiadał wybitne, różnorodne zdolności, choć równocześnie był raczej odludkiem, z mnóstwem przyzwyczajeń przypisywanym starym kawalerom. Ponadto był niezwykle sprawny fizycznie. Miał zwyczaj gimnastykowania się i chodzenia pieszo do szkoły w Niesky $(40 \mathrm{~km}$ $\mathrm{w}$ jedną stronę). Był bardzo przywiązany do swego trybu życia i zupełnie nie miał ochoty na wyjazd w Himalaje. Jednakże wola wspólnoty była w takich przypadkach nadrzędna ${ }^{20}$.

H.A. Jaeschke dotarł do Keylongu w Lahulu w 1857 r., a więc w czasie, kiedy ten obszar znajdował się zaledwie od dziesięciu lat pod zarządem brytyjskim. Dzięki temu rozszerzeniu wpływów Brytyjskiej Wschodnioindyjskiej Kompanii Handlowej, Pagell i Heyde uzyskali pomoc od angielskich władz administracyjnych. Otrzymali grunt pod budowę misji, a także kawałek pola, który przekształcili w ogród owocowo-warzywny. Jednakże moment na rozpoczęcie działań misyjnych był niefortunny. Wybuchło bowiem Powstanie Sipajów ${ }^{21}$ i towarzyszące mu antybrytyjskie wystąpienia. Miały one co prawda małe nasilenie na obszarze himalajskim, ale powszechna niechęć do Brytyjczyków dotykała również morawian, ponieważ byli oni utożsamiani z przedstawicielami administracji kolonialnej. Okoliczni mieszkańcy nie odróżniali Niemców od Brytyjczyków, a także misjonarzy od oficerów. W konsekwencji kontakty z miejscowymi notablami były utrudnione, a brytyjska zwierzchność i pomoc stała się niemal fikcją, ponieważ najbliższy wysoki urzędnik (Assistant Comissioner) zarządzał sprawami z Kulu ${ }^{22}$ i bardzo rzadko odwiedzał daleki Lahul. Z dostępnych sprawozdań wynika jednak, że okres rewolucji antybrytyjskiej nie spowodował żadnego zagrożenia życia dla morawian, natomiast opóźnił ich adaptację i zakorzenienie się w lokalnym środowisku.

Gdy już minął przeszło rok mojej pracy nad materiałami archiwalnymi, byłem ciekaw, czy jestem w stanie w terenie himalajskim, po tak wielu dekadach, zlokalizować misje morawskie i na miejscu czegokolwiek się dowiedzieć o codziennym życiu ich założycieli. Liczne relacje cykliczne zamieszczane w periodykach misyjnych nie były zbyt wiarygodne, poza tym nie przekazywały szczegółów

${ }^{20}$ Dostępne dokumenty, w tym zapiski Jaeschkego, nie wspominają, czy w przypadku jego kandydatury jako lingwisty i kierownika misji tybetańskiej, również dokonano w Herrnhucie „losowania”, by zdać się na boską wyrocznię, czy też była to zdroworozsądkowa decyzja władz wspólnoty.

${ }^{21}$ Powstanie sipajów w źródłach brytyjskich nazywane jest najczęściej „Indian Mutiny”.

${ }^{22}$ Historycznie Kulu było jedyną dużą wsią na tym obszarze. Ze względu na obecność władz kolonialnych, traktowane było jak miasteczko, choć większość mieszkańców utrzymywała się $\mathrm{z}$ rolnictwa. 
dotyczących realiów dni powszednich ${ }^{23}$. Ich zadaniem było, przede wszystkim, informowanie opinii publicznej o działaniach ewangelizacyjnych, jak i pomoc w zbiórce funduszy. Po dość długich poszukiwaniach miejsca funkcjonowania stacji misyjnej w Keylongu (otoczenie zmieniło się znacznie), odnalazłem lekarkę zatrudnioną w miejscowym szpitalu, która była właścicielką dużej części zabudowań przynależących kiedyś do misji ${ }^{24}$. W tym obrębie znajdował się bardzo przemyślnie zaprojektowany budynek, złożony z kilku modułów mieszkalnych, a także pomieszczeń gospodarczych. Tym, co nawet dzisiaj go wyróżnia wśród gęstej zabudowy wsi, są kominy. Jedyne kominy w otoczeniu budynków historycznych $^{25}$. Przyznaję, że na to nie wpadłem do razu, a znacznie uprościłoby mi to poszukiwania. Najstarsza część wsi usytuowana jest na zboczu doliny, co ułatwia obserwację dachów „z góry”. A ja szukałem budynków wedle założenia, że zauważę odmienne od lokalnego stylu cechy architektoniczne, a ponadto szukałem ich "poniżej buddyjskiego klasztoru”, kierując się dawnymi relacjami. Tymczasem klasztorów było w tej miejscowości już kilka, zabudowa bardzo zagęszczona, a nikt z mieszkańców nie pamiętał żadnych misjonarzy. W tym miejscu warto dodać, że morawianie nie wznosili kościołów, których bryły uławiałyby znalezienie misji. Najczęściej miejscem modlitwy i stosownych rytuałów było duże pomieszczenie wewnątrz budynków mieszkalnych (świetlica). Dlatego też nie miało sensu szukanie dzwonnicy, wieży czy budynku sakralnego. Na szczęście starsze pokolenie żyje coraz dłużej, także w Himalajach. W końcu udało mi się uzyskać informację o misjonarzach dzięki pośrednictwu młodej osoby, której dziadek był kiedyś nauczycielem w miejscowej szkole. Niestety i on nie znał osobiście morawian, ale za to wiedział doskonale, gdzie mieściła się ich siedziba.

W momencie pierwszego wejścia do budynku, towarzyszyły mi różnorakie uczucia. Od spełnienia, satysfakcji, zauroczenia, do rezygnacji i beznadziei. Podświadomie liczyłem, iż zastanę wnętrza $\mathrm{w}$ takim stanie, $\mathrm{w}$ jakim przedstawił je na rysunku H.A. Jeaschke, choć szanse na to były niewielkie, ponieważ

\footnotetext{
${ }^{23}$ Muszę wyjaśnić, iż morawianie wydawali własne periodyki: Missionsblattaus der Brüdergemeine w Herrnhucie oraz Periodical Accounts Relating to the Missions of the Church of the United Brethren, Established among the Heathen (także pod nieco zmienioną nazwą od $1890 \mathrm{r}$.), w Londynie, oprócz zamieszczania licznych relacji we wspólnych misyjnych czasopismach protestanckich.

${ }^{24}$ Rozdrobnienie dawnej własności morawskiej poważnie utrudnia odtworzenie dziejów działek i zabudowań misyjnych. W większości morawianie sprzedali za bezcen lub rozdali swą własność pomiędzy członków lokalnych wspólnot w chwili likwidacji stacji w Lahulu i Kinnaurze. Współczesne rodziny albo nie chcą, albo nie potrafią podać szczegółów historycznych. Nie natrafiłem na żaden dokument potwierdzający darowiznę lub sprzedaż. Wygląda na to, że przejęcie dokonało się przez zasiedzenie, a później dawna ziemia misyjna podlegała dalszej odsprzedaży.

25 Systemy ogrzewania podobne do zastosowanego przez morawian mają tylko budynki rządowe, wzniesione $\mathrm{w}$ ostatnich 30-40 latach: szpitalne, szkolne, administracyjne. Zresztą jedna $\mathrm{z}$ dwóch działających przychodni medycznych mieści się $\mathrm{w}$ dawnym budynku misyjnym o tym samym przeznaczeniu. $W$ tym przypadku ogrzewanie umożliwiało już $w$ XIX $w$. przeprowadzanie zabiegów chirurgicznych nawet zimą. Sprawa niebagatelna, bo w Keylongu termometry mogą wskazywać nawet $-25^{\circ} \mathrm{C}$.
} 
stację przebudowywano ${ }^{26}$. Pomieszczenia były pozbawione europejskich mebli, drobiazgów tworzących dawną atmosferę. Jedynym elementem wskazującym na „obcość" kulturową było to, iż części mieszkalne i kuchnia (wspólna) miały murowane kominki, które przez obecnych właścicieli nie są używane. W tradycyjnych domostwach zachodniohimalajskich nie stosowano kominów. Były one wyposażone w palenisko do przygotowywania posiłków, które znajdowało się $\mathrm{w}$ pomieszczeniu pełniącym zarazem funkcję kuchni i salonu; było to jedyne pomieszczenie ogrzewane w całym domu. Kiedyś funkcję grzewczą pełniła konstrukcja gliniana, później (aż do współczesności) piecyk stalowy typu "koza”. Miałem więc poczucie, że się poważnie spóźniłem. Pierwotni właściciele dawno temu wyjechali. Nie zastałem więc ich w domu i uświadomiłem sobie, że już nic mi nie opowiedzą. Drobną rekompensatą była możliwość poszperania na strychu budynku, który sprawiał wrażenie, jakby nikt tam nie zaglądał od czasów Braci Morawskich. I znowu spotkał mnie zawód; wkoło był tylko kurz. Nie było tam jakichkolwiek przedmiotów, które mogłyby należeć do misjonarzy; żadnych papierów, drobiazgów, które w wyobraźni naiwnie tam umiejscawiałem. Kilka starych gazet, jakie tam się poniewierały, pochodziło już z czasów niepodległych Indii.

Więcej szczęścia miałem na zewnątrz. Obejście misji przypominało stan sprzed ponad stu lat. Wręcz niewiarygodne, ale wciąż można było rozeznać założenie przydomowego ogrodu, położenie rabat kwiatowych i warzywnych grządek. Brak było, niestety, drzew owocowych. Bardzo mi na ich znalezieniu zależało, ponieważ chciałem potwierdzić w terenie ewentualną rolę Europejczyków w popularyzowaniu sadownictwa na obszarach wysokogórskich ${ }^{27}$. Na dużej części działki pobudowano nowe domy; nie było zatem śladu po części rolnej. Wkoło domu zostało trochę winorośli, którą tak cenił A.W. Heyde. Nic więcej nie mogłem zrobić poza wykonaniem dokumentacji fotograficznej. Próbowałem jeszcze znaleźć kogoś, kto mógłby dysponować jakąś wiedzą na temat misjonarzy, pamiątkami z tamtej epoki, ale bezskutecznie. Miałem do dyspozycji szereg nazwisk członków lokalnej kongregacji chrześcijańskiej, ale ich potomkowie niechętnie przyznawali się do swego rodowodu. W sprawach dotyczących podziału gruntów misji, wymownie zasłaniali się niewiedzą, a w ich oczach pojawiała się niechęć do poruszania tego rodzaju tematów, tak jakby nagabywał ich jakiś urzędnik państwowy, który jest władny coś im zabrać. Może gdybym mógł tam zostać przez kilka miesięcy, to udałoby się czegoś więcej dowiedzieće ${ }^{28}$.

${ }^{26}$ Wedle sprawozdań morawskich, główny budynek misji został odbudowany po częściowym zawaleniu się podczas trzęsienia ziemi w $1901 \mathrm{r}$.

${ }^{27}$ Morawianie pisali sporo o swych wysiłkach $\mathrm{w}$ introdukowaniu rozmaitych rośli użytkowych, jednak bardzo trudno wnioskować tylko na tej podstawie. Dawne odmiany nie zostały szczegółowo opisane, a współcześnie wiele instytucji zajmowało się propagowaniem upraw warzyw i owoców. Na ile morawianie przyczynili się do zmiany lokalnej struktury upraw rolnych, pozostanie już pewnie nierozwiązaną zagadką.

${ }_{28}$ Moje późniejsze wizyty w Keylongu także nie przyniosły dodatkowych informacji na temat podziału własności misyjnej po jej zamknięciu. Materiały archiwalne nie są precyzyjne w tej kwestii, tym samym nie ułatwiają poszukiwań. 
Powróćmy do dokonań H.A. Jaeschkego - wspomniałem, że był on utalentowanym rysownikiem. Jako miłośnik pieszych wędrówek, przemierzał spore odległości bądź to w celach śledzenia zróżnicowania językowego, czy też w ramach swych codziennych obowiązków kierowniczych i nauczycielskich, bądź też tylko dla relaksu. Niektóre ze szlaków mogłem odtworzyć podczas pobytów w Indiach. Wędrowanie po tych samych drogach i ścieżkach sprawiło mi niebywałą przyjemność, choć nie było to łatwe. Jaeschke naprawdę musiał być świetnym piechurem. Przejście niektórych ze szlaków opisanych w jego listach i raportach zajmuje dobrych kilka godzin, a on potrafił je przemierzać codziennie w drodze do i ze szkoły utworzonej dla lokalnych dzieci. Odtwarzanie niegdysiejszych marszrut miało też cel praktyczny. Chciałem rozwiązać kilka zagadek, które pozostałyby tajemnicą bez konfrontacji $z$ warunkami w terenie. Jaeschke niektóre ze swych obserwacji notował, a inne uwieczniał w rysunkach. Tak też miała się sprawa ze szkicami znalezionymi przeze mnie w jego Dzienniku, zdeponowanym w herrnhuckim archiwum ${ }^{29}$. Na kartach widniały zarysy grani górskich, jakieś nieopisane budynki, rośliny, pomniejsze doliny rzeczne. Bez możliwości zobaczenia tych miejsc na własne oczy, nie byłbym w stanie ich umiejscowić, choć nie wszystkie z nich udało się zidentyfikować.

Wspomniany Dziennik Jaeschkego jest niezwykle cennym źródłem do badań nad początkami tworzenia misji morawskiej w Lahulu, jak też do poznania osobowości „ojca tybetologii”. Z dotychczas odcyfrowanych fragmentów wyłania się obraz osoby pedantycznej, niezmiernie pracowitej, choć wręcz nieszczęśliwej z powodu utracenia swej „małej stabilizacji” w Saksonii. O tym, w jaki sposób działał on w Himalajach, dowiedzieć się można analizując jego wczesne, kierownicze decyzje powzięte bezpośrednio po przybyciu z Europy (w roku 1857). Do tego czasu, Heyde i Pagell próbowali się dostosować do miejscowych warunków. Mając niemal trzyletnie doświadczenie przebywania w Indiach północnych ${ }^{30}$, uznali, że aby ich poważano, powinni nosić ubiory buddyjskich lamów. Zrezygnowali także ze spożywania mięsa i, żeby zapewnić sobie źródło nabiału, kupili krowę ${ }^{31}$. Sami pracowali w ogrodzie i przy wznoszeniu budynków, jednakże ta aktywność

${ }_{29}$ Zachował się jedynie pierwszy wolumin dziennika H.A. Jaeschkego, który dotyczy roku 1857 i części następnego. Tekst w nim zawarty został zapisany w ośmiu językach podstawowych (angielskim, francuskim, niemieckim, duńskim, szwedzkim, polskim, greką i po łacinie). Wtrącenia i pojedyncze znaki dodatkowo w hindi (znakami dewanagari) i tybetańskim. Od niemal dziesięciu lat trwają zespołowe prace tłumaczeniowe i redakcyjne, zainicjowane przeze mnie i Johna Bray'a. Niestety, na razie bez pozytywnego rezultatu.

${ }^{30}$ Heyde i Pagell dużo podróżowali w latach 1853-1856, próbując znaleźć najdogodniejsze miejsce na założenie misji, aby rozpoznać drogę do Tybetu, spotykać się z lokalnymi arystokratami i przedstawicielami władz brytyjskich.

${ }^{31}$ Wątek powstrzymania się od spożycia mięsa w pierwszym roku działania misji w Keylongu uznaję za niezwykle interesujący. Pagell i Heyde podróżowali po Indiach północnych od roku 1853; byli dobrymi obserwatorami, a ponadto kontaktowali się z doświadczonymi misjonarzami pracującymi na obszarach hinduistycznych. Ich decyzja nie wynikała z ignorancji. Z kolei na obszarze w przeważającej mierze buddyjskim, spożycie mięsa nie stanowiło problemu, raczej jego pozyskanie (nie było w Keylongu muzułmańskich rzeźników, którzy zwyczajowo zajmowali się ubojem). Skłaniam się do zdania, że okresowy wegetarianizm miał ich sytuować wysoko zarówno w hierarchii hinduistycznej (arystokracja), jak i buddyjskiej (wyrzeczenie). 
nie spotkała się z aprobatą lamów z pobliskiego klasztoru położonego na zboczu, ok. 200 metrów wyżej. Bliskie kontakty umożliwiały prowadzenie wielu rozmów i sporów dotyczących zasad etycznych w obu systemach religijnych. Cóż więcej powiedzieć. Starali się ze wszystkich sił znaleźć w nieprzewidywalnych dla Europejczyków warunkach; chcieli dostosować się, aby być osobami poważanymi i zajmując taką pozycję móc oddziaływać na otoczenie.

Pierwsze zarządzenia Jaeschkego po objęciu kierownictwa misji tybetańskiej, były radykalnie odmienne. Polecił ubić krowę, zrobić z jej mięsa kiełbasy, zlecił wypiek chleba oraz powrót do europejskiego ubioru, a właściwie do morawskiego czarnego surduta i kapelusza z szerokim rondem, takiegoż koloru. Jaeschke nie chciał jechać do Indii ani do Tybetu. Skoro jednak tak się stało, uznał za celowe odtworzenie warunków domowych, zbliżonych do niemieckich. Zaskoczyły mnie w tekście Dziennika liczne fragmenty odnoszące się do jadłospisu obiadów. Genialny tłumacz był małostkowy. Cieszył się niemal jak dziecko, gdy posiłek składał się ze sztuki mięsa, ziemniaków i kompotu ${ }^{32}$. W tym samym czasie przestrzegał rygorystycznie rytów modlitewnych, a wszelkie przedsięwzięcia misyjne realizował kierując się zasadami wczesnej doktryny morawskiej, w imię której należało je powierzyć boskiemu wstawiennictwu.

Dla zrównoważenia opisu skupionego na morawianach, pozwolę sobie na nierozbudowaną refleksję osobistą. Długotrwały pobyt $\mathrm{w}$ terenie zmienia priorytety zarówno badacza, jak i misjonarza. Przywiązanie do drobiazgów, drobne natręctwa, to elementy, które trudno jest zrozumieć komuś, kto nigdy nie poczuł osierocenia przez własną kulturę, zagubienia w innym świecie. To jest ta sytuacja, na którą zwrócił uwagę Bronisław Malinowski, pisząc, że wówczas nagle ceni się szmirowatą literaturę i marnotrawi czas na jej lekturę ${ }^{33}$. Chyba każdy z "terenowców" doświadczył tego uczucia. Żeby mu przeciwdziałać, stukrotnie przegląda się jedyną gazetę przywiezioną z domu. Jest to działanie, które przypomina notoryczne dłubanie w bolącym zębie. To skomplikowana kwestia. Przedstawiam ją studentom, by za pomocą wyobraźni przekraczali swe granice i potrafili przygotować się do włączania "trybu terenowego", gdy będzie im potrzebny. Ćwiczenie to, choć jego sens może wydawać się ograniczony, przynosi pożądane skutki już $\mathrm{w}$ sytuacji badawczej. Trochę przygotowuje na nieznane i łagodzi obawy przed spotkaniem z „obcym" ${ }^{\prime 34}$.

Małostkowy Jaeschke rozpoznał w ciągu roku sytuację językową dużej części północnych Indii, nauczył się kilku lokalnych języków i tybetańskiego. Dla kogokolwiek, kto miał z tymi językami do czynienia, jest jasne, że jego zdolności lingwistyczne były nieprzeciętne. Przygotował bardzo wiele prób przekładów fragmentów Nowego Testamentu, opracował podręczniki szkolne, poświęcał czas rozległej korespondencji prywatnej i służbowej. Ze względu na stan zdrowia

\footnotetext{
${ }^{32}$ Jaeschke, Diary, 219-220.

${ }_{33}$ Malinowski, B., Dziennik w ścistym znaczeniu tego wyrazu. Warszawa 2008: Wydawnictwo Literackie.

${ }^{34} \mathrm{~W}$ kontekście wspomnianego ćwiczenia, "obcym” jest każdy człowiek poza badaczem, a nawet „nieoswojone” zjawisko kulturowe.
} 
przebywał w Lahulu niecałe dziewięć lat. Resztę prac, z których jest znany i dzięki którym zyskał nieśmiertelność wśród zainteresowanych tybetańskim obszarem kulturowym, napisał mieszkając ponownie w Saksonii. Między rokiem 1865 a 1883 powstały liczne przekłady Pisma Świętego, a nade wszystko słowniki, angielsko- i niemiecko-tybetańskie. Wydane w roku 1881 i 1883, są do dziś uznawane przez wielu tybetologów za najlepsze $\mathrm{z}$ dostępnych ${ }^{35}$.

Gdy wspominam lata swoich pierwszych wędrówek śladami morawian, przypominam sobie, jak natrętnie sam porównywałem się z nimi. Irytowały mnie rozmaite moje niekompetencje: językowe, terenowe, osobowościowe. Zawodowa, a wówczas także młodzieńcza, buta podpowiadała mi, że przecież mogę analizować czyjąkolwiek działalność, gdyż mam po temu odpowiednie narzędzia. Niestety, była to ułuda. Nie da się zastosować podejścia zbliżonego do postawy "emic" w stosunku do postaci historycznych, znanych z aktywności trwającej dekady, podczas krótkich - miesięcznych, dwumiesięcznych pobytów terenowych. To niezbyt konstruktywne uczucie nie chciało mnie opuścić. Gdy w końcu, po latach badań, byłem w stanie szczegółowo odtworzyć spektrum zajęć morawian w Lahulu i ich misyjnych dokonań, wciąż ogarniał mnie wstyd przed samym sobą, powiązany z refleksją, że pracuję zbyt wolno, nieefektywnie, i że nie potrafię poświęcić się wyłącznie badaniom. Zdawałem sobie sprawę, że nie dorównuję postaciom, które próbuję opisywać. Liczne tłumaczenia, także prac badawczych (w przypadku kolejnych pokoleń morawian), powstałych w trakcie dni wypełnionych codziennymi obowiązkami gospodarczymi, logistycznymi, ewangelizacyjnymi, nauczycielskimi i innymi, najpierw wprawiały mnie w osłupienie, a dopiero po chwili potrafiłem podziwiać ich efektywność. Dysponowałem coraz większą ilością materiałów dotyczących „misji tybetańskiej”, co pozwoliło na odtworzenie chronologii aktywności i poczynań misjonarzy. Niektóre lata ich pobytu mogłem dość dokładnie zrekonstruować. Znałem zakres podejmowanych wówczas zajęć i ich okresowe natężenie. Jednakże nawet najbogatsze dane nie pozwalały poczuć bliskiej więzi z postaciami, z którymi poniekąd przebywałem codziennie, przez kilka lat ${ }^{36}$. Odczucie pustki, nieprzekładalności, nie było jednak tak dotkliwe, gdy mogłem usiąść spokojnie pośród budynków dawnych misji w Keylongu lub w Pooh (okręg Kinnaur); postać wśród zabudowań, zaglądnąć do pomieszczeń, w których morawianie pracowali i odpoczywali, czy odkryć kadry z archiwalnych zdjęć.

${ }^{35}$ Oczywiście w związku z klasycznym tybetańskim. Odniesienia słownikowe stanowią obszerny temat rozważań, którego tutaj nie sposób omawiać. Kilka osób, co do których kwalifikacji językowych nie mam wątpliwości, Piotr Klafkowski, Bettina Zeisler, Alex McKay, John Bray, potwierdzało wielokrotnie $\mathrm{w}$ rozmowach, że dokonania Jaeschkego należy traktować jako wiekopomne, nie tylko ze względu na znawstwo, ale i wielką dozę intuicji językowej, niezastąpionej przy tworzeniu tak poważnych dzieł.

36 Prace nad archiwaliami morawskimi rozpocząłem w 1998 r., a opracowanie w postaci pracy doktorskiej nastąpiło $\mathrm{w}$ roku 2006. W późniejszych latach przygotowałem kilka publikacji artykułowych, jak i monografię (2011), a także jej poprawione wydanie angielskojęzyczne: The Moravian Brethren and Himalayan Cultures: Evangelisation, Society, Industry. https://www. academia.edu/28260462/Beszterda_Moravian_Brethren_and_Himalayan_Cultures.pdf 
Jedno z takich zdarzeń szczególnie mnie dotknęło, a równocześnie dość brutalnie odsłoniło realia życia misjonarzy morawskich. Pod koniec lat 90. przebywałem w Pooh (Kinnaur) i rozmawiałem z ówczesnymi mieszkańcami dawnych budynków misyjnych. Niewiele potrafili mi o tym miejscu opowiedzieć, za to podobały im się archiwalne zdjęcia tego miejsca i okolic utrwalane od lat 60. XIX w., których skany miałem ze sobą. Zgromadzeni wokół mnie przywołali sąsiadów i już w szerszym gronie zaczęli komentować te zdjęcia; wskazywali, co się zmieniło, kto i gdzie ma pola, identyfikowali ulice, świątynie, a także zwracali uwage na wygląd i ubiór mieszkańców uwiecznionych na fotografiach. Jakby w rewanżu zaczęli przynosić drobiazgi z wnętrza swych domostw, pytając, czy przypadkiem nie są one „morawskie”. Jeden z mężczyzn wyniósł spory kamień, który okazał się płytą nagrobną Josefa Eduarda, niespełna rocznego syna Theodora i Mary Schreve (zmarł w 1893 r.) $)^{37}$. Ten epizod miał kilka podstawowych odniesień. Wedle opisów archiwalnych, za siedzibą misji znajdował się kiedyś cmentarz, którego teren potem zaorano. Mieszkańcy widzieli, że chodziłem po tym miejscu i czegoś tam szukałem. Ponoć do lat 80. ubiegłego wieku zachowało się tam kilka nagrobków, które zabrali do Europy krewni zmarłych, ale miejscowi nie potrafili przypomnieć sobie szczegółów, nazwisk ani pochodzenia przyjezdnych. Sporo misjonarskich rodzin doświadczyło śmierci swych krewnych podczas misji. Niemal połowa dorosłych nie wytrzymywała wieloletniego życia w wysokogórskich warunkach. Keylong, jak i później założone stacje w Pooh, Leh i okolicznych wsiach, były położone powyżej 3300 m n.p.m. Niektórzy dla poratowania zdrowia wyjeżdżali na roczne urlopy na niziny indyjskie lub do Europy, inni umierali.

Mam też inną refleksję, która pojawiła się w swym pełnym kształcie dopiero po latach pracy z archiwaliami, a zarazem po kilku pobytach terenowych. Dwaj morawianie, którzy założyli misję himalajską w Keylongu, byli najtwardsi. Mimo że Heyde i Pagell nie posiadali błyskotliwych umysłów na miarę Jaeschkego, ich mozolna i długotrwała praca (od 1859 r. przebywali wraz z żonami) umożliwiła stabilność stacji przy minimalnych kosztach subwencji europejskiej, ale też zapoczątkowała kierunek trwałych zmian gospodarczych i założenie pionierskiej sieci placówek edukacyjnych w Lahulu. Bez przesady można powiedzieć, że misje morawskie pod ich zarządem ${ }^{38}$ były pierwszymi nowoczesnymi instytucjami społecznymi w całym pasie zachodniohimalajskich Indii. August Wilhelm Heyde spędził w Indiach pół wieku, przez większą część tego okresu ze swą żoną Marie. Eduard Pagell żył tam 30 lat (zmarł wraz ze swą małżonką w Pooh, w 1883 r.). „Ojcowie założyciele” misji wykorzystywali swe rzemieślnicze umiejętności.

37 T.D.L. Schreve, wraz z żoną, przebywał w Pooh w latach 1890-1903 r., z roczną przerwą na podratowanie zdrowia (1898-1899). Z drugiego urlopu, w 1903 r., już nie wrócili w Himalaje. Wyjechali na misję do Południowej Afryki i tam oboje zmarli (1930). Płyta nagrobna ich syna została na początku XXI w. zabrana przez krewnych do Niemiec, a przynajmniej taką wiadomość mi przekazano.

${ }^{38}$ Po wyjeździe H.A. Jaeschkego do Europy w 1865 r., kierownictwo misji w Keylongu objął A.W. Heyde. Natomiast E. Pagell założył nową stację w Pooh, Kinnaur (1865). Kierował nią do swej śmierci w $1883 \mathrm{r}$. 
Zaplanowali i zrealizowali system nawadniania, w znacznym stopniu uniezależniający grunty misyjne i wiejskie od opadów bieżących. Zaprojektowali wielkopołaciowe pola tarasowe, co było nowatorskim rozwiązaniem, ułatwiającym prace rolne $\mathrm{z}$ wykorzystaniem zaprzęgu. Wprowadzili uprawę dziesiątek gatunków warzyw i owoców, nieznanych lokalnie bądź niedocenianych. Pokazali mieszkańcom i nauczyli ich, jak wykorzystywać siłę wspólnoty (zakupy hurtowe, podział pracy, wzajemne wspomaganie się, spójny opór wobec niesprawiedliwości arystokratów, czy narzucanym bezprawnie podatkom). W całej historii morawskich działań w północnych Indiach żaden z późniejszych misjonarzy nie spędził tam tylu lat, co ci dwaj pionierzy. Ta wytrwałość i znajomość terenu, mieszkańców, specyfiki kulturowej i warunków gospodarowania, przynosiły znakomite efekty, ale tylko dzięki ich osobistemu zaangażowaniu, i pod ich nadzorem. Gdy zabrakło Pagella i Heydego, nikt nie potrafił sprostać codziennym wyzwaniom w tak szerokim zakresie. Misje w Lahulu i Kinnaurze stopniowo zamierały, a w końcu zostały zamknięte ${ }^{39}$. Wiele z morawskich rozwiązań gospodarczych i społecznych zostało zapomnianych na dekady. Odżyły jednak w niemal identycznej postaci w niepodległych Indiach. Czy był to choćby w części skutek dawnej akcji edukacyjnej prowadzonej przez morawian? Chyba nikt nie potrafi dzisiaj o tym przesądzić.

\section{Epilog}

Zakończyłem prace nad morawskimi materiałami misyjnymi sześć lat temu. Zatem nie powinienem zbyt często do nich sięgać. Jednakże szeroki zakres ich dokonań $\mathrm{w}$ terenie i opracowane publikacje sprawiają, że wciąż znajduję $\mathrm{w}$ tym obszarze jakieś nowe inspiracje, zauważam problemy, których wcześniej nie dostrzegałem. Zresztą z biegiem lat przybywających "na karku”, rośnie także mój sentymentalizm. Podczas każdego pobytu w Himalajach odwiedzam dawne misje. Pokazuję zdjęcia, archiwalne i te wykonane przez siebie przed laty. Próbuję nimi zainteresować nie tylko sąsiadów dawnych misji, ale i nauczycieli, a także uczniów w lokalnych szkołach. Czuję, że propagowanie wiadomości o morawianach jest moim obowiązkiem i robię to z przyjemnością. W dodatku wiem, jakie szczepy winogron, które grusze i śliwy tam rosnące są odmianami zasadzonymi ponad wiek temu. To nader miłe uczucie, gdy wiadomo, że gdzieś daleko zawsze czeka namiastka domu. Teren staje się coraz bardziej „oswojony".

Jest jeszcze jeden wątek, którego pominięcie byłoby nietaktem. Za sprawą zainteresowania się morawianami z Herrnhutu, zyskałem spore grono znajomych,

${ }^{39}$ Po kilkudziesięciu latach działalności morawian na obszarze Lahulu funkcjonowała misja główna w Keylongu, a oprócz niej kilka stacji lokalnych; w Kinnaurze misja, w Pooh także działała jako główna, wraz z ośrodkami mniejszego znaczenia w Dobbaling i Dobling (w których rozpoczęto nauczanie dzieci). Formalnie misje morawskie $w$ tych dwóch okręgach zamknięto na początku lat 40. XX w., choć opuszczono je faktycznie niemal dwie dekady wcześniej. Misjonarze i większa część konwertytów przeniosła się do Leh w Ladakhu (stacja założona w 1885 r.). Jest to jedyne miejsce, gdzie morawian można spotkać do dzisiaj. 
zawodowych i prywatnych. Niewiarygodne, jak wiele osób, z rozmaitych dyscyplin naukowych, zetknęło się z dokonaniami morawian i z nich czerpało inspiracje do swoich badań. Cóż, byli to nieprzeciętni ludzie. Nie tylko w Himalajach. Od Grenlandii, przez Karaiby, Labrador, po Ziemię Ognistą, trudno prowadzić badania etnologiczne i nie skorzystać z pozostawionych przez nich materiałów. Życzę sobie wielokrotnie, bym miał tyle zapału, co oni i potrafił tak efektywnie wykorzystywać dany mi czas.

\section{Literatura}

Anderson, R. (1874). Foreign Missions: Their Relations and Claims. Boston: Congregational Publishing Society.

Beszterda, R. (2011). Bracia Morawscy a kultury himalajskie. Ewangelizacja, społeczeństwo, gospodarka. Wrocław-Warszawa: PTL i IAE PAN

Bray, J. (1990). A History of the Moravian Church's Tibetan Bible Translations. W: G. Meier, L. Icke-Schwalbe (ed.), Wissenschaftsgeschichte und gegenwärtige Forschungen in Nordwest-Indien (66-79). Dresden: Museum of Ethnology.

Bray, J. (2005). Early Protestant Missionary Engagement with the Himalayan Region and Tibet. W: J. Bray (red.), Ladakhi Histories. Local and Regional Perspectives (249-270). Leiden: Brill.

Jeaschke, H.A., Diary [niepublikowany rękopis]. Archiv der Brüdegemeine, Herrnhut.

Reetzke, J. (2000-2001). Count Zinzendorf. A Brief History of the Lord's Recovery, vol. 1-2. Chicago: Bibles and Books.

\section{SUMMARY}

Following the first Moravian missionaries in the Himalaya

The Moravian Brethren formed a very particular community within the Protestant Church. Above all, they had a distinct understanding of the Christian ministry and, consequently, their group had a disctinct missionary character. They were the first to undertake Protestant missions among peoples living far from the centers of civilization and administrative power. This paper describes the author's encounter with the Himalayan cultures and traces of Moravian missionaries' work in the area, discerned over many years of research focusing on the past European activity, its contexts and the durability of cultural solutions it promoted.

Keywords: Moravian Church, missionaries, H.A. Jaeschke, A.W. Heyde, E. Pagell, cultural change, Kinnaur, Lahaul, Ladakh 